\title{
Detection of regional scale sea-to-air oxygen emission related to spring bloom near Japan by using in-situ measurements of the atmospheric oxygen/nitrogen ratio
}

\author{
H. Yamagishi ${ }^{1}$, Y. Tohjima ${ }^{1}$, H. Mukai ${ }^{2}$, and K. Sasaoka ${ }^{3}$ \\ ${ }^{1}$ Atmospheric Environment Division, National Institute for Environmental Studies, Tsukuba, Japan \\ ${ }^{2}$ Center for Global Environmental Research, National Institute for Environmental Studies, Tsukuba, Japan \\ ${ }^{3}$ Frontier Research Center for Global Change, Japan Agency for Marine-Earth Science and Technology, Yokohama, Japan
}

Received: 19 November 2007 - Published in Atmos. Chem. Phys. Discuss.: 6 February 2008

Revised: 13 May 2008 - Accepted: 19 May 2008 - Published: 27 June 2008

\begin{abstract}
We have been carrying out in-situ monitoring of atmospheric $\mathrm{O}_{2} / \mathrm{N}_{2}$ ratio at Cape Ochi-ishi (COI; $43^{\circ} 10^{\prime} \mathrm{N}$, $145^{\circ} 30^{\prime} \mathrm{E}$ ) in the northern part of Japan since March 2005 by using a modified gas chromatography/thermal conductivity detector (GC/TCD). The standard deviation of the $\mathrm{O}_{2} / \mathrm{N}_{2}$ ratio is estimated to be about \pm 14 per meg $(\approx 3 \mathrm{ppm})$ with intervals of 10 minutes. Thus, the in-situ measurement system has a $1 \sigma$ precision of \pm 6 per meg $(\approx 1.2 \mathrm{ppm})$ for one-hour mean $\mathrm{O}_{2} / \mathrm{N}_{2}$ ratio. Atmospheric potential oxygen $\left(\mathrm{APO} \approx \mathrm{O}_{2}+1.1\right.$ $\mathrm{CO}_{2}$ ), which is conserved with respect to terrestrial photosynthesis and respiration but reflects changes in air-sea $\mathrm{O}_{2}$ and $\mathrm{CO}_{2}$ fluxes, shows large variabilities from April to early July 2005. Distribution of satellite-derived marine primary production indicates occurrences of strong bloom in the Japan Sea and the latitudinal band between $30^{\circ}$ and $40^{\circ} \mathrm{N}$ in the western North Pacific in April and in the Okhotsk Sea and northeastern region near Hokkaido Island in the North Pacific in June. Back trajectory analysis of air masses indicates that high values of APO, which last for several hours or several days, can be attributed to the oxygen emission associated with the spring bloom of active primary production.
\end{abstract}

\section{Introduction}

Observation of atmospheric oxygen has been conducted for decades since the development of methods for measuring atmospheric $\mathrm{O}_{2} / \mathrm{N}_{2}$ ratios (e.g. Keeling, 1988; Bender et al., 1994). Changes in atmospheric $\mathrm{O}_{2}$ have been applied to

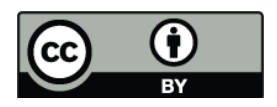

Correspondence to: H. Yamagishi (yamagishi.hiroaki@ nies.go.jp) resolve the carbon budget, exploiting the nature of the molar $\mathrm{O}_{2}: \mathrm{C}$ exchange ratios in fossil fuel combustion (Keeling, 1988) and in land biotic photosynthesis and respiration (Severinghaus, 1995). For oceanic fluxes, exchange of $\mathrm{O}_{2}$ is much faster than that of $\mathrm{CO}_{2}$. It takes only 3 weeks for dissolved oxygen to equilibrate with the atmosphere, whereas it takes about a year for $\mathrm{CO}_{2}$ because of the different equilibration time scales of various carbonate species (Broecker and Peng, 1982). Therefore, because of the apparent independence of the air-sea exchange of $\mathrm{CO}_{2}$ and $\mathrm{O}_{2}$ due to the fast response of $\mathrm{O}_{2}$ relative to $\mathrm{CO}_{2}$, seasonal variations in atmospheric oxygen have been used to estimate marine productivity (Keeling and Shertz, 1992; Bender et al., 1996; Balkanski et al., 1999).

Stephens et al. (1998) introduced Atmospheric Potential Oxygen $\left(\mathrm{APO} \approx \mathrm{O}_{2}+1.1 \mathrm{CO}_{2}\right)$ as a conservative tracer for $\mathrm{O}_{2}$ and $\mathrm{CO}_{2}$ exchange related to land biotic photosynthesis and respiration. The concept of APO is similar to the oceanic component of the $\mathrm{O}_{2} / \mathrm{N}_{2}$ ratio, which has been discussed by Keeling and Shertz (1992). Although spatial and temporal distributions of APO have been revealed through flask sample measurements (Battle et al., 2006; Manning and Keeling, 2006; Tohjima et al., 2005b), there are short-term APO variations that can not be detected from flask sampling. At stations such as Cold Bay, Alaska (CBA: $55^{\circ} \mathrm{N}, 162^{\circ} \mathrm{E}$ ) (Battle et al., 2006) and Cape Ochi-ishi, Hokkaido (COI; $43^{\circ} 10^{\prime} \mathrm{N}$, $145^{\circ} 30^{\prime} \mathrm{E}$ ) (Tohjima et al., 2003), plots of APO are scattered, which may be related to variation of $\mathrm{O}_{2}$ flux from the oceans caused by active marine primary production near the stations.

In-situ measurements at stations can significantly increase the temporal resolution of atmospheric $\mathrm{O}_{2}$ measurements, leading to new insights into marine productivity and air-sea oxygen flux on even smaller time and space scales. Various

Published by Copernicus Publications on behalf of the European Geosciences Union. 
techniques have been developed to make in-situ measurements of the atmospheric $\mathrm{O}_{2} / \mathrm{N}_{2}$ ratio, such as the paramagnetic oxygen analyzer system (Lueker et al., 2003; Manning et al., 1999), the vacuum ultraviolet absorption method (Stephens, 1999; Stephens et al., 2003), and the fuel cell analyzer systems (Stephens et al., 2007 and references therein). Previous studies have revealed that a sampling line for insitu $\mathrm{O}_{2} / \mathrm{N}_{2}$ measurements requires careful design to prevent fractionation of $\mathrm{O}_{2}$ from $\mathrm{N}_{2}$. Thermal fractionation between $\mathrm{O}_{2}$ and $\mathrm{N}_{2}$ can easily occur at various locations, such as the sampling line inlet (Blaine et al., 2006; Stephens et al., 2007; Sturm et al., 2006) and tee junctions (Keeling et al., 2004; Manning, 2001; Stephens et al., 2003).

Tohjima (2000) developed an analytical system for measuring $\mathrm{O}_{2} / \mathrm{N}_{2}$ ratio by using a gas chromatograph equipped with a thermal conductivity detector (GC/TCD). The GC/TCD method has been used to analyze flask samples collected at monitoring stations and cargo ships (Tohjima et al., 2003; Tohjima et al., 2005b) and has the potential to be applied for field based $\mathrm{O}_{2} / \mathrm{N}_{2}$ measurements. In this study, we set up a field-base $\mathrm{O}_{2} / \mathrm{N}_{2}$ measurement system at COI, which is located at the eastern coast of Hokkaido island in Japan. APO at COI shows large variability especially during spring and summer (Tohjima et al., 2003). To examine the causes of the variability of APO at COI, we have monitored the $\mathrm{O}_{2} / \mathrm{N}_{2}$ ratio since 17 March 2005. Here, we show the details of the in-situ measurement system and the quality and reliability of the obtained data. We also made analysis of short-term variations (temporal scales of several hours to days) in APO from April to early July 2005 using back trajectory analysis and found that the APO variation can be attributed to the regional-scale oxygen emission resulting from spring bloom in the Japan Sea, the Okhotsk Sea, and the western North Pacific.

\section{Methods}

\subsection{Sampling line}

An air intake, which is covered with an inverted equilateral triangular pole with a roof (a side is $40 \mathrm{~cm}$ and the height is $\sim 1 \mathrm{~m}$ ), is placed on the tower at $\sim 51 \mathrm{~m}$ height above ground level ( $\sim 100 \mathrm{~m}$ height above sea level) at COI. Sample air is drawn through $1 / 2$ inch OD copper tubing from the tower to the inside of the station using an oil-free diaphragm pump (model MOA-P108-HB, Gast Mfg. Corp., Benton Harbor, MI, USA) at a rate of $\sim 8 \mathrm{~L} \mathrm{~min}^{-1}$. This fast sample flow rate was chosen to prevent thermal fractionation between $\mathrm{O}_{2}, \mathrm{~N}_{2}$, and Ar at the inlet of the sample line (Keeling et al., 1998). We examined the diurnal variations of APO to confirm that thermal fractionation does not affect the $\mathrm{O}_{2} / \mathrm{N}_{2}$ ratio measurement at COI significantly (see Sect. 3.1 for details).

The measurement system requires an $8 \mathrm{~mL} \mathrm{~min}^{-1}$ flow rate, which is one thousandth of the main flow rate of the sample gas. Previous studies have found that the fractionation of $\mathrm{O}_{2}$ from $\mathrm{N}_{2}$ occurs at a tee junction when there is a thermal gradient in the tee junction or the flow ratio between the two separated flows is large (Keeling et al., 2004; Manning et al., 1999; Stephens et al., 2003). To separate the sample gas without fractionation at tee junctions, Stephens et al. (2007) have developed a special tee configuration, in which a thin pick-off tubing extends upstream into a larger OD tubing. In our case we inserted a 2-L spherical Pyrex ${ }^{\circledR}$ glass flask into the main sample flow as a buffer volume for picking up the required small sample gas flow for measurement (see Fig. 1).

After the air sample is drawn from the intake with a $1 / 4^{\prime \prime}$ tubing, it is passed through a 7- $\mu \mathrm{m}$-pore-sized filter and a 2$\mu \mathrm{m}$-pore-sized filter in a stainless housing and compressed into the spherical flask at a pressure of $0.06 \mathrm{MPa}$ above atmospheric pressure by the diaphragm pump (see Fig. 1 for details of the sample line). The pressure in the spherical flask is adjusted using a back pressure valve. A drain port on the spherical flask removes water condensed from vapor in the air sample manually. The air sample is then collected from the center of the spherical flask using a 1/16 inch OD, $0.80 \mathrm{~mm}$ ID stainless steel tubing (SUS 316) at a continuous flow rate of $8 \mathrm{~mL} \mathrm{~min}{ }^{-1}$.

After sample collection, the air sample is dried further by passing through an $80-\mathrm{mL}$ Pyrex ${ }^{\circledR}$-glass trap immersed in an alcohol bath $\left(-80^{\circ} \mathrm{C}\right)$. We prepare four glass traps that can be changed one by one, but only one is used at any one time. Usually the glass trap does not get clogged with ice for one month running because OD of the glass trap is enlarged $(4 \mathrm{~cm})$ at the location where ice can form. In the summer time, however, we did on rare occasions find traps clogged with ice within a month. When that occurred, we replaced the clogged trap with the next one remotely through the computer measurement program. It takes about $1-2 \mathrm{~h}$ for sample gas in the replaced glass trap to stabilize. Thus, we have discarded one or two outliers from the one-hour mean $\mathrm{O}_{2} / \mathrm{N}_{2}$ ratios after replacing a glass trap. The alcohol bath is cooled using a low temperature freeze trap VA-500F (Taitec Corp., Koshigaya, Japan). Although a large temperature gradient in the glass trap leads to large gradients of $\mathrm{O}_{2}$ and $\mathrm{N}_{2}$ between the bottom and top of the trap, the constant flow of the sample ensures a constant $\mathrm{O}_{2} / \mathrm{N}_{2}$ ratio for air flowing into and out of the cold trap (Keeling et al., 1998). To prevent fractionation, we keep the flow of the air sample constant and use a 1/16 inch OD, 0.030 inch ID passivation-layer-coated Silcosteel ${ }^{\circledR}$ tubing (Restek Corp., Bellefonte, PA, USA) at the sample line where the temperature gradient exists. The dried sample is then introduced into the sample line of the $\mathrm{O}_{2} / \mathrm{N}_{2}$ ratio measurement system for analysis (see Tohjima (2000) for details of the measurement line). 


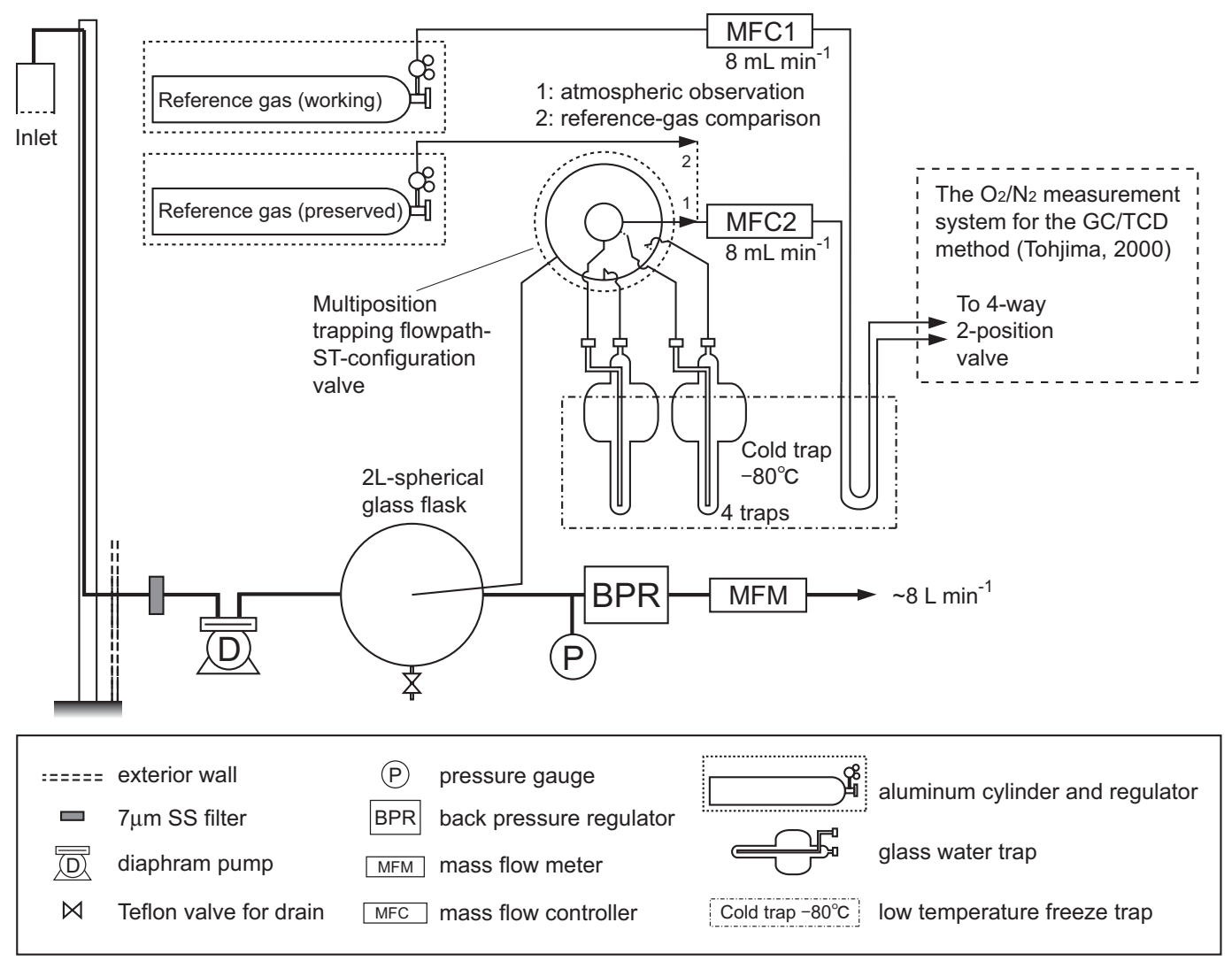

Fig. 1. Schematic diagram of the sampling line for the in-situ $\mathrm{O}_{2} / \mathrm{N}_{2}$ measurement system using the GC/TCD method developed by Tohjima (2000).

Briefly, the dried sample is further passed through a second cold trap $\left(-80^{\circ} \mathrm{C}\right)$ that is $\sim 70 \mathrm{~cm}$ long, $1 / 8$ inch OD nickel tubing. Working or reference gases are also passed through a similar type of cold trap. Then, sample or working gases are induced into a sample loop ( $2 \mathrm{~mL}$ volume, $1 / 16$ inch OD nickel tubing) alternatively by turning a Valco ${ }^{\circledR}$ 4-way 2position valve (Valco Instruments Co. Inc., Houston, USA). The $2 \mathrm{~mL}$ sample or working gases are injected into a separation column that is composed of a $2 \mathrm{~m}$ long, $1 / 8$ inch OD, $2.17 \mathrm{~mm}$ ID stainless steel tubing packed with 50/80 mesh molecular sieve 5A (MS-5A). One measurement takes about $4.5 \mathrm{~min}$; working and sample gasses are injected every $5 \mathrm{~min}$ by a Valco ${ }^{\circledR}$ 6-way 2-position valve. Although $\mathrm{CO}_{2}$ will be trapped in the MS-5A column, the accumulation of $\mathrm{CO}_{2}$ is unlikely to affect the $\mathrm{O}_{2} / \mathrm{N}_{2}$ ratio measurement within a month.

For long-term monitoring, the rotors of Valco ${ }^{\circledR}$ 4-way and 6-way valves should be replaced about once a year if the rotor material is Valcon-M (VICI, USA). When a rotor is composed of Valcon-M, scale-shaped fractions are produced by the friction of rotation and then fill the dips of the rotor, which worsen the precision. We recommend the material of Valcon-E for 4-way and 6-way valves. Fraction of this mate- rial becomes fine powder, which will not fill the dips of the rotors. The rotors can be used for more than one year.

\subsection{Instruments and gas handling descriptions}

Some components of the measurement system differ from those shown by Tohjima (2000). We use a GC-323(W) GC/TCD (GL Sciences Inc., Tokyo, Japan; hereinafter abbreviated as GC-323) as the detector instead of the HewlettPackard (HP) 5890 GC/TCD to improve precision. Precision of the $\mathrm{O}_{2} / \mathrm{N}_{2}$ ratio is sensitive to temperature fluctuations of the separation column and the TCD detector (see Tohjima (2000) for details of the components in the measurement system). Thus, the heaters for the TCD and oven, as well as the fan in the GC oven, are turned off to prevent temperature fluctuations. Temperature fluctuations of the sample loop and the reference volumes for differential pressure sensors are also minimized by insulating them from room temperature. During the period of 17 March 2005-21 February 2006, analog output of the TCD has been digitized using a HewlettPackard 3396 Series II Integrator (USA). On 22 February 2006, the HP integrator was replaced by a 24-bit A/D converter (ChromatoDAQ, Ulvac Inc., Chigasaki, Japan). Measurements, data acquisition, and calculation of peak area are 
performed using Visual Basic ${ }^{\circledR}$ (Microsoft Corp., Redmond, USA) since 22 February 2006.

In the GC/TCD, hydrogen gas (99.99999\%) is used as the carrier gas, supplied by a Hydrogen Generator H2-300JA100 (Parker Balston, Haverhill, USA). The carrier gas is introduced into the sample and reference cells of the TCD at a flow rate of $30 \mathrm{~mL} \mathrm{~min}^{-1}$. Purified natural air in a $48-\mathrm{L}$ aluminum cylinder compressed to a pressure of $\sim 8 \mathrm{MPa}$ is used as a reference gas. Concentrations of $\mathrm{O}_{2}, \mathrm{~N}_{2}, \mathrm{Ar}$, and $\mathrm{CO}_{2}$ of the purified air are adjusted as required by adding $\mathrm{O}_{2}$, Ar, and $\mathrm{CO}_{2}$ into the cylinder (Tohjima et al., 2008). Two reference gas cylinders are sent to the monitoring station once a year. These cylinders are placed horizontally in heat-insulated wooden boxes to prevent thermal fractionation. Each cylinder is used as a working gas successively at a continuous flow rate of $8 \mathrm{~mL} \mathrm{~min}^{-1}$.

Once a month, maintenance of the measurement system is carried out. The separation column is baked at $320^{\circ} \mathrm{C}$ for $300 \mathrm{~min}$ and the vapor traps (both the $80-\mathrm{mL}$ glass traps and the $1 / 8^{\prime \prime}$ OD nickel tubing traps) are dried. During maintenance, two reference gas cylinders are compared to check stability of the $\mathrm{O}_{2} / \mathrm{N}_{2}$ ratio. When the pressure of the cylinder being used decreases to $\sim 2 \mathrm{MPa}$, it is replaced with the second one. One cylinder lasts for more than 6 months. Working gas cylinders are used up to the fractional usage of 0.75. Although Keeling et al. (2004) found the fractionations of the $\mathrm{O}_{2} / \mathrm{N}_{2}$ and $\mathrm{Ar} / \mathrm{N}_{2}$ ratios in their working-gas cylinders, we found that the $\mathrm{O}_{2} / \mathrm{N}_{2}$ ratio in our cylinders stays within 4 per meg before and after deployment at the monitoring station, indicating no significant drift. The averaged $\mathrm{O}_{2} / \mathrm{N}_{2}$ ratio is, therefore, applied to the $\mathrm{O}_{2} / \mathrm{N}_{2}$ ratio of each reference gas cylinder.

\subsection{Data processing}

Changes of the $\mathrm{O}_{2} / \mathrm{N}_{2}$ ratio are expressed as relative deviations from a reference gas according to:

$\delta\left(\mathrm{O}_{2} / \mathrm{N}_{2}\right)=\frac{\left(\mathrm{O}_{2} / \mathrm{N}_{2}\right)_{S}}{\left(\mathrm{O}_{2} / \mathrm{N}_{2}\right)_{R}}-1$,

where subscripts $S$ and $R$ denote sample and reference gases, respectively. Normally, the value of $\delta\left(\mathrm{O}_{2} / \mathrm{N}_{2}\right)$ is multiplied by $10^{6}$ and expressed as per meg unit (Keeling and Shertz, 1992). The scale of the reference gas used in the present study is described elsewhere (Tohjima et al., 2008). The ratio of the $\left(\mathrm{O}_{2}+\mathrm{Ar}\right)$ peak area to the $\mathrm{N}_{2}$ peak area is directly determined from the peak areas of a $\left(\mathrm{O}_{2}+\mathrm{Ar}\right)$ peak and a $\mathrm{N}_{2}$ peak of the GC/TCD signal (as shown in Fig. 1 of Tohjima, 2000). To improve the reproducibility of the areas, a chromatogram is smoothed by conducting a 21-point running mean and then a 25-point Savitzky-Golay smoothing. Since the baseline between the $\left(\mathrm{O}_{2}+\mathrm{Ar}\right)$ and $\mathrm{N}_{2}$ peaks is not completely flat, the end point of the $\left(\mathrm{O}_{2}+\mathrm{Ar}\right)$ peak and the start point of the $\mathrm{N}_{2}$ peak are made identical. The end point of the $\mathrm{N}_{2}$ peak is fixed to a certain time after sample injection.
With the TCD sensitivity ratio of Ar relative to $\mathrm{O}_{2}$ being expressed by $k$, the $\left(\mathrm{O}_{2}+\mathrm{Ar}\right)$ peak area is related to the mole fractions of $\mathrm{O}_{2}$ and Ar. One may define (Tohjima et al., 2000):

$\delta\left\{\left(\mathrm{O}_{2}+\mathrm{Ar}\right) / \mathrm{N}_{2}\right\}=\frac{\left\{\left(\mathrm{X}_{\mathrm{O}_{2}}+k \mathrm{X}_{\mathrm{Ar}}\right) / \mathrm{X}_{\mathrm{N}_{2}}\right\}_{S}}{\left\{\left(\mathrm{X}_{\mathrm{O}_{2}}+k \mathrm{X}_{\mathrm{Ar}}\right) / \mathrm{X}_{\mathrm{N}_{2}}\right\}_{R}}-1$.

The value of $k$ for HP5890 is slightly different from the one for GC-323 ( $k_{\mathrm{HP}}=1.13$ (Tohjima et al., 2005a) and $k_{\mathrm{GL}}=1.08$, where the subscript symbols represent HP5890 and GC-323, respectively). Assuming that the value of $k\left(\mathrm{X}_{\mathrm{Ar}} / \mathrm{X}_{\mathrm{N}_{2}}\right)_{S^{-}}$ $k\left(\mathrm{X}_{\mathrm{Ar}} / \mathrm{X}_{\mathrm{N}_{2}}\right)_{R}$ is zero for any samples and reference gases (see Tohjima (2000) for details), $\delta\left(\mathrm{O}_{2} / \mathrm{N}_{2}\right)$ is related to $\delta\left\{\left(\mathrm{O}_{2}+\mathrm{Ar}\right) / \mathrm{N}_{2}\right\}$ :

$\delta\left(\mathrm{O}_{2} / \mathrm{N}_{2}\right)=\delta\left\{\left(\mathrm{O}_{2}+\mathrm{Ar}\right) / \mathrm{N}_{2}\right\} \times\left\{\left(\mathrm{X}_{\mathrm{O}_{2}}+k \mathrm{X}_{\mathrm{Ar}}\right) / \mathrm{X}_{\mathrm{O}_{2}}\right\}_{R}$,

where $\left\{\left(\mathrm{X}_{\mathrm{O}_{2}}+k \mathrm{X}_{\mathrm{Ar}}\right) / \mathrm{X}_{\mathrm{O}_{2}}\right\}_{R}$ is a scaling factor (1050 for HP5890 (Tohjima et al., 2005a) and 1.048 for GC323). If the sample $\mathrm{Ar} / \mathrm{N}_{2}$ ratio increases by $\sim 20$ per meg, the $\mathrm{O}_{2} / \mathrm{N}_{2}$ ratio measured by the GC/TCD method is overestimated by $\sim 1$ permeg; this is based on the assumption of a constant $\mathrm{Ar} / \mathrm{N}_{2}$ ratio (definition of $\mathrm{Ar} / \mathrm{N}_{2}$ ratio is as follows: $\delta\left(\mathrm{Ar} / \mathrm{N}_{2}\right)=\left\{\left(\mathrm{Ar} / \mathrm{N}_{2}\right)_{\text {sample }} /\left(\mathrm{Ar} / \mathrm{N}_{2}\right)_{\text {reference }}-1\right\} \times 10^{6}$ (per meg)). This is a valid assumption, since changes in the $\mathrm{Ar} / \mathrm{N}_{2}$ ratio are not likely to be significant in the present analysis of short-term variability in the $\mathrm{O}_{2} / \mathrm{N}_{2}$ ratio, because short term variability in the $\mathrm{Ar} / \mathrm{N}_{2}$ ratio is less than 30 per meg (see Battle et al., 2003; Blaine et al., 2006). Since we apply a constant to the $\mathrm{O}_{2} / \mathrm{N}_{2}$ ratio of each reference gas cylinder, the assumption of a constant $\mathrm{Ar} / \mathrm{N}_{2}$ ratio can also be adopted for the working gas.

We found that the value of $\delta\left\{\left(\mathrm{O}_{2}+\mathrm{Ar}\right) / \mathrm{N}_{2}\right\}$ measured by GC-323 $\left(\delta\left\{\left(\mathrm{O}_{2}+\mathrm{Ar}\right) / \mathrm{N}_{2}\right\}_{\mathrm{GL}}\right)$ is not always equal to that measured by HP5890 GC/TCD $\left(\delta\left\{\left(\mathrm{O}_{2}+\mathrm{Ar}\right) / \mathrm{N}_{2}\right\}_{\mathrm{HP}}\right)$ when we measure the same set of cylinders. The linearity of HP5890 GC/TCD was found to lie within $\pm 1 \%$ based on the measurements of purified air gases that cover wide range of $\mathrm{O}_{2} / \mathrm{N}_{2}$ ratio (Tohjima et al., 2005a); the difference of $\delta\left\{\left(\mathrm{O}_{2}+\mathrm{Ar}\right) / \mathrm{N}_{2}\right\}$ measured by two different types of TCD could be attributed to a nonlinear behavior of GC-323 GC/TCD (see details in Sect. 2.4). The area ratio of $\delta\left\{\left(\mathrm{O}_{2}+\mathrm{Ar}\right) / \mathrm{N}_{2}\right\}_{\mathrm{GL}}$ is then corrected from the following equation:

$\delta\left\{\left(\mathrm{O}_{2}+\mathrm{Ar}\right) / \mathrm{N}_{2}\right\}_{\mathrm{HP}}=\delta\left\{\left(\mathrm{O}_{2}+\mathrm{Ar}\right) / \mathrm{N}_{2}\right\}_{\mathrm{GL}} / L$,

where $L$ is the linearity correction factor for GC-323 ( $L=1.078 \pm 0.004$ at COI; Serial No. is GC-323-0338.). Note that the factor $L$ is different for individual GC-323 GC/TCDs. Slight difference in the value of the factor $k$ (the TCD sensitivity ratio of Ar relative to $\mathrm{O}_{2}$ ) between HP5890 and GC-323 can not explain the difference in the linearity of $\delta\left\{\left(\mathrm{O}_{2}+\mathrm{Ar}\right) / \mathrm{N}_{2}\right\}$. 
Table 1. Results of linearity calibration experiments.

\begin{tabular}{llll}
\hline GC/TCD & $\delta\left\{\left(\mathrm{O}_{2}+\mathrm{Ar}\right) / \mathrm{N}_{2}\right\}_{\mathrm{S} 1 / \mathrm{S} 2}($ per meg) & Linearity correction factor, $L^{\mathrm{a}}$ Date of experiments \\
\hline $\mathrm{HP} 5890$ & $491.3 \pm 1.4$ & - & - \\
$\mathrm{GC}-323$ & $529.7 \pm 1.9$ & $1.078 \pm 0.005$ & $19-20 / \mathrm{Feb} / 2007$ \\
$\mathrm{GC}-323$ & $529.3 \pm 1.8$ & $1.077 \pm 0.005$ & $18-19 / \mathrm{Mar} / 2007$ \\
GC-323 (average) & - & $1.078 \pm 0.004$ & - \\
\hline
\end{tabular}

${ }^{\text {a }}$ Symbols of S1 and S2 represent cylinders of CPB-26855 and CPB-17279, respectively. Values of $\delta\left\{\left(\mathrm{O}_{2}+\mathrm{Ar}\right) / \mathrm{N}_{2}\right\}_{\mathrm{HP}}$ of the cylinders S1 and S2 were estimated at $63.3 \pm 1.0$ and $-428.0 \pm 1.0$ per meg, respectively. Value of $\delta\left\{\left(\mathrm{O}_{2}+\mathrm{Ar}\right) / \mathrm{N}_{2}\right\}_{\mathrm{S} 1 / \mathrm{S} 2}$ represents $\delta\left\{\left(\mathrm{O}_{2}+\mathrm{Ar}\right) / \mathrm{N}_{2}\right\}$ of the cylinder $\mathrm{S} 1$ relative to that of $\mathrm{S} 2$.

Here, APO is calculated by the following equation:

$\delta \mathrm{APO}=\delta\left(\mathrm{O}_{2} / \mathrm{N}_{2}\right)+\alpha_{B} \mathrm{X}_{\mathrm{CO}_{2}} / \mathrm{X}_{\mathrm{O}_{2}}-1850$ (per meg),

where $\mathrm{X}_{\mathrm{CO}_{2}}$ is the $\mathrm{CO}_{2}$ mol fraction in ppm, $\alpha_{B}$ is the $\mathrm{O}_{2}: \mathrm{C}$ molar exchange ratio for the land biotic respiration and photosynthesis $\left(\alpha_{B}=1.1\right), \mathrm{X}_{\mathrm{O}_{2}}$ is the atmospheric $\mathrm{O}_{2}$ mole fraction $\left(\mathrm{X}_{\mathrm{O}_{2}}=0.2094\right.$ (Tohjima et al., 2005a), and the value 1850 is the arbitrary APO reference point (Tohjima et al., 2005b). We have calculated APO using in-situ $\mathrm{CO}_{2}$ data obtained from the monitoring station (Mukai et al., 2001).

\subsection{Linearity correction for TCD response}

To estimate the linearity correction factor for the in-situ measurement system, we selected two 10L-aluminum cylinders of the purified air that is synthesized gravimetrically by Tohjima et al. (2005a). High and low $\mathrm{O}_{2} / \mathrm{N}_{2}$ ratio values of the two gravimetric standards cover the range of the variation of $\mathrm{O}_{2} / \mathrm{N}_{2}$ ratio observed at $\mathrm{COI}$. Before and after calibration experiments, the ratios of $\delta\left\{\left(\mathrm{O}_{2}+\mathrm{Ar}\right) / \mathrm{N}_{2}\right\}_{\mathrm{HP}}$ in gravimetric standards were estimated in our laboratory using an HP 5890 GC/TCD. After relocation to the monitoring station, the two cylinders of the gravimetric standards were heat-insulated and kept horizontal for a month. The gravimetric standards were then measured as a sample gas relative to the working gas using a GC-323 GC/TCD in February and March 2007. We calculated the values of $\delta\left\{\left(\mathrm{O}_{2}+\mathrm{Ar}\right) / \mathrm{N}_{2}\right\}_{\mathrm{GL}}$ between gravimetric standards and estimated the linearity correction factor for each experiment (see Table 1). The linearity correction factor remained relatively constant for a month between the before- and after-calibration experiments (see Table 1). In our laboratory, we also examined the linearity of another GC-323 GC/TCD by measuring cylinders and samples for more than two years. The linear correlation between $\delta\left\{\left(\mathrm{O}_{2}+\mathrm{Ar}\right) / \mathrm{N}_{2}\right\}_{\mathrm{HP}}$ and $\delta\left\{\left(\mathrm{O}_{2}+\mathrm{Ar}\right) / \mathrm{N}_{2}\right\}_{\mathrm{GL}}$ stays within a range of $\sim 2000$ per meg and the slope of the correlation does not change significantly during the periods. Considering these results, we have adopted a constant value of $1.078 \pm 0.004$ for the linearity correction factor for the in-situ measurement system at COI (Table 1).

Although we have not yet identified the cause of the nonlinearity inherent in GC-323, the difference in the linearity

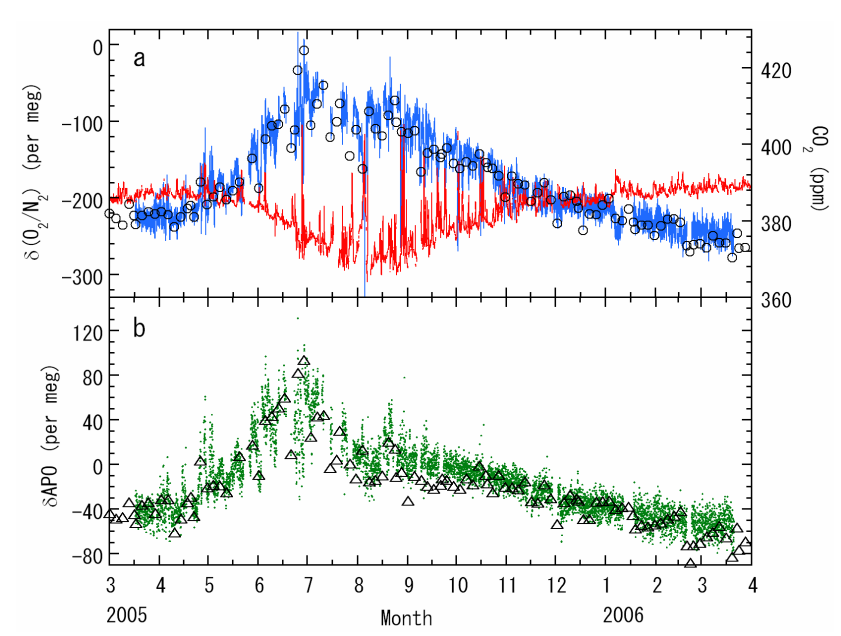

Fig. 2. One-hour mean $\mathrm{O}_{2} / \mathrm{N}_{2}$ ratio (blue line, a), $\mathrm{CO}_{2}$ mole fraction (red line, a), and $\delta$ APO (green dot, b) measured in situ at Cape Ochi-ishi from March 2005 to March 2006. Open circles (a) and open triangles (b) represent $\mathrm{O}_{2} / \mathrm{N}_{2}$ ratio and $\delta \mathrm{APO}$, respectively, of flask samples.

between these two instruments might be related to the difference in the physical structure between GC-323 and HP 5890 TCDs. Basically, TCD consists of four filaments in a Wheatstone bridge configuration. In GC-323, two filaments are exposed to the reference gas, and the other two filaments are exposed to the sample gas. In contrast, in the HP5890 detector only one TCD filament is exposed alternately to the reference and sample gases very rapidly.

\section{Discussion and results}

\subsection{Precision and data evaluation}

The in-situ $\mathrm{O}_{2} / \mathrm{N}_{2}$ ratio and $\mathrm{CO}_{2}$ mole fraction measurements from March 2005 to March 2006 are shown in Fig. 2a and APO is shown in Fig. 2b. The standard deviation of the $\mathrm{O}_{2} / \mathrm{N}_{2}$ ratio was estimated at $\sim \pm 14$ per meg $(1 \sigma)$ for half a day measurements when intra-hourly room temperature fluctuation was $0.5-1^{\circ} \mathrm{C}$. Thus, standard error (SE) for 1 -h mean 

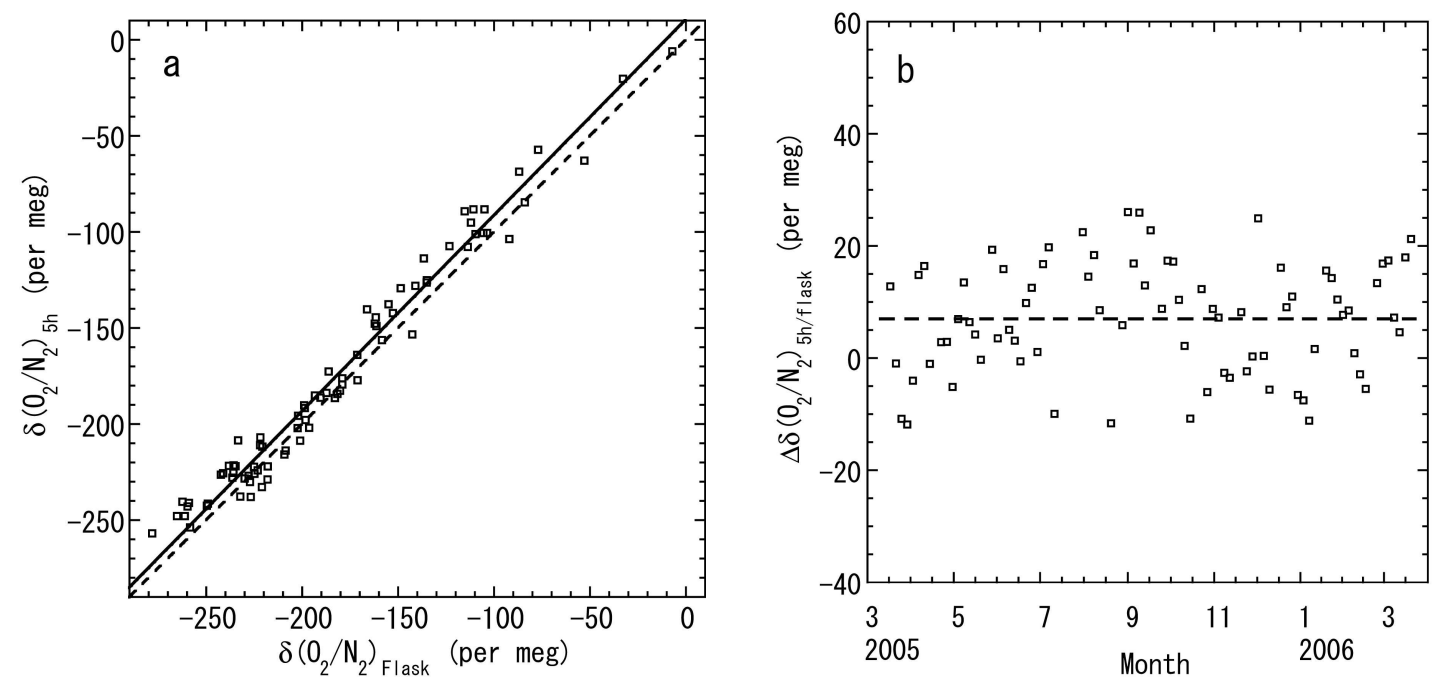

Fig. 3. Comparison of $\delta\left(\mathrm{O}_{2} / \mathrm{N}_{2}\right)$ between the flask, $\delta\left(\mathrm{O}_{2} / \mathrm{N}_{2}\right)_{\text {flask }}$, and the 5-h mean in-situ $\mathrm{O}_{2} / \mathrm{N}_{2}$ ratio, $\delta\left(\mathrm{O}_{2} / \mathrm{N}_{2}\right) 5 \mathrm{~h}$, from 17 February 2005 to 20 March 2006. (a) Solid and broken lines are the reduced measure axis regression $(Y=1.02 X+10.5)$ and the function of $Y=X$, respectively. Plot represents the 5-h mean $\delta\left(\mathrm{O}_{2} / \mathrm{N}_{2}\right)$ measured in situ. (b) Deviation of the in-situ measurements from the flask measurements (i.e. $\Delta \delta\left(\mathrm{O}_{2} / \mathrm{N}_{2}\right)_{5} \mathrm{~h} /$ flask $=\delta\left(\mathrm{O}_{2} / \mathrm{N}_{2}\right)_{5 \mathrm{~h}}-\delta\left(\mathrm{O}_{2} / \mathrm{N}_{2}\right)_{\text {flask }}$ ). Broken line represents $Y=7.0$, which is an average of the deviation.

$\mathrm{O}_{2} / \mathrm{N}_{2}$ ratio was $\sim \pm 6$ per meg $(1.2 \mathrm{ppm})$. During August 2005 and from December 2005 to May 2006, the standard deviation of the $\mathrm{O}_{2} / \mathrm{N}_{2}$ ratio increased to $20-30$ per meg because the range of room temperature fluctuation increased to $\sim 2^{\circ} \mathrm{C}$. To reduce the influence of the room temperature fluctuation on the measurement precision, on 24 May 2006 GC/TCD and the sample loop were heat-insulated in an aluminum box, with the space between the inside and the outside plates of the box filled with water. This resulted in a stabilization of the $\mathrm{O}_{2} / \mathrm{N}_{2}$ ratio with a standard deviation of $\sim \pm 14$ per meg.

The in-situ $\mathrm{O}_{2} / \mathrm{N}_{2}$ ratio values were compared with those obtained from flask samples. As shown in Fig. 3a, there is a linear correlation between $\delta\left(\mathrm{O}_{2} / \mathrm{N}_{2}\right)$ from the flask sampling, $\delta\left(\mathrm{O}_{2} / \mathrm{N}_{2}\right)_{\text {flask }}$, and the in-situ 5-h mean $\mathrm{O}_{2} / \mathrm{N}_{2}$ ratio, $\delta\left(\mathrm{O}_{2} / \mathrm{N}_{2}\right)_{5} \mathrm{~h}$. The difference between $\delta\left(\mathrm{O}_{2} / \mathrm{N}_{2}\right)_{5} \mathrm{~h}$ and $\delta\left(\mathrm{O}_{2} / \mathrm{N}_{2}\right)_{\text {flask }}$ (denoted as $\Delta \delta\left(\mathrm{O}_{2} / \mathrm{N}_{2}\right)_{5} \mathrm{~h} /$ flask $)$ during March 2005-March 2006 is shown in Fig. 3b. The value of $\Delta \delta\left(\mathrm{O}_{2} / \mathrm{N}_{2}\right)_{5} \mathrm{~h} /$ flask was estimated to be $7.0 \pm 9.9$ per meg $(1 \sigma$, $n=79$ ), whereas the difference between the in-situ 1-h mean $\mathrm{O}_{2} / \mathrm{N}_{2}$ ratio and the ratio from the flask measurements $\left(\Delta \delta\left(\mathrm{O}_{2} / \mathrm{N}_{2}\right)_{1 \mathrm{~h} / \text { flask }}\right)$ was found to be $8.4 \pm 12.7$ per meg $(1 \sigma$, $n=79)$.

Although we have not yet clearly identified the cause of the difference noted above, it is likely that a positive fractionation of $\mathrm{O}_{2}$ relative to $\mathrm{N}_{2}$ occurs in the sampling line (Fig. 1). Stephens et al. (2003) reported a fractionation of $\mathrm{O}_{2}$ relative to $\mathrm{N}_{2}$ by as much as 70 per meg when air sample flowing at a rate of $80 \mathrm{~mL} \mathrm{~min}^{-1}$ was separated from the main sample flow $\left(6 \mathrm{~L} \mathrm{~min}^{-1}\right)$ by the tee junction located just before the BPR. In order to reduce the fractionation, they installed a $2 \mathrm{~m}$ of $1 / 4^{\prime \prime}$ tubing before the BPR and reduced the main flow rate to $2 \mathrm{~L} \mathrm{~min}^{-1}$. In our system, air sample is allowed to flow for about $30 \mathrm{~cm}$ in a stainless steel tubing (1/4" OD, $4.35 \mathrm{~mm}$ ID) from the spherical flask to the BPR at a rate of $\sim 8 \mathrm{~L} \mathrm{~min}^{-1}$. We have confirmed that the back pressure regulator is not the cause of the bias. We added a $6 \mathrm{~mm} \mathrm{OD}, 4 \mathrm{~m}$ long Dekabon ${ }^{\circledR}$ tubing coil between the spherical glass flask and the back pressure regulator on 22 August 2007. However, the bias still remains at the same extent after the installation of the long tubing coil (data are not shown). The Teflon cock attached on the spherical glass flask may cause a small leaking to fractionate $\mathrm{O}_{2}$ and $\mathrm{N}_{2}$ and then accumulate $\mathrm{O}_{2}$ in the spherical flask.

The standard deviation of $\Delta \delta\left(\mathrm{O}_{2} / \mathrm{N}_{2}\right)_{1 \mathrm{~h} / \text { flask }}$ $( \pm 12.7$ permeg $)$ is larger than the expected standard error (SE) of $\pm \sim 8$ per meg based on the SE of individual measurements from flasks ( $\mathrm{SE}= \pm 5$ per meg) and in-situ measurements ( $\mathrm{SE}= \pm 6$ per meg for 1 -h mean $\mathrm{O}_{2} / \mathrm{N}_{2}$ ratio). The reasons for this could be due to the following factors: (1) Increase in the fluctuation of the room temperature during August 2005 and from December 2005 to May 2006 may have increased the standard error of $\Delta \delta\left(\mathrm{O}_{2} / \mathrm{N}_{2}\right)_{1 \mathrm{~h} / \text { flask }}$ by $\sim 1$ per meg, and (2) Changes in the cold trap temperature may have contributed to the fractionation of $\mathrm{O}_{2}$ from $\mathrm{N}_{2}$ as the air sample passed through the $80-\mathrm{mL}$ glass trap. There are other possible factors, such as the temporal variability of the $\mathrm{O}_{2} / \mathrm{N}_{2}$ ratio of the working gas and the difference in the sampling time for flasks and in-situ measurements.

Thermal fractionation at the intake has also been examined to evaluate the influence on the in-situ measurement of the $\mathrm{O}_{2} / \mathrm{N}_{2}$ ratio. If the thermal fractionation has affected the 

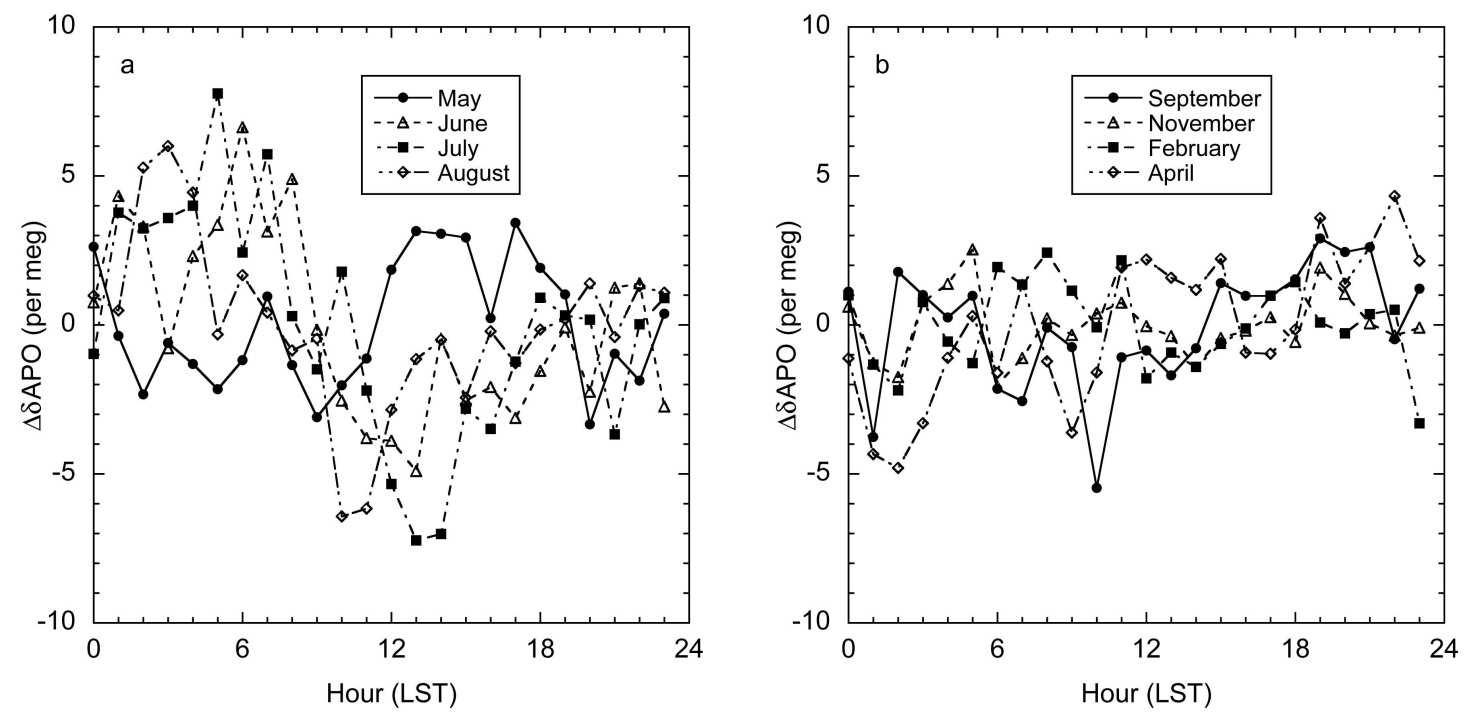

Fig. 4. Monthly-averaged diurnal variations of Atmospheric Potential Oxygen on clear days for the months of (a) May, June, July, August, (b) September, November, February, and April for Ochi-ishi between March 2005 and December 2007. These averaged diurnal variations were determined from deviations of hourly APO from the daily means for individual months. Averaged standard errors and numbers of data (shown in parenthesis) for each month are as follows; (a) May: \pm 2.1 ( $n=35)$, Jun: \pm 3.3 ( $n=31)$, Jul.: \pm 2.4 ( $n=28)$, Aug.: \pm 2.3 ( $n=30)$, (b) Sep.: \pm 1.5 ( $n=35)$, Nov.: $\pm 1.1(n=35)$, Feb.: $\pm 1.7(n=21)$, and Apr.: \pm 2.0 (per meg) $(n=26)$. Half of the observational data was selected as the data for clear days based on the median values of solar radiation.

$\mathrm{O}_{2} / \mathrm{N}_{2}$ ratio measurement significantly, a decline of APO will be observed when the inlet is heated by solar radiation, as reported by Blaine et al. (2006), Stephens et al. (2007), and Sturm et al. (2006). However, we hardly found such typical variations in the time series of the observed APO. To examine the diurnal variability of APO more precisely, we selected data observed on clear days (based on solar radiation measurements) and computed monthly-averaged diurnal APO variations (Fig. 4). The results show that there are no apparent diurnal cycles within a range of \pm 5 per meg from October to May. Although we found significant diurnal cycles from June to September, we consider these diurnal cycles to reflect the actual variability because solar radiation was almost the same between May and July. Therefore, we conclude that the thermal fractionation should not affect our $\mathrm{O}_{2} / \mathrm{N}_{2}$ ratio measurement within the range of analytical precision.

\subsection{Atmospheric observation}

The observed $\mathrm{O}_{2} / \mathrm{N}_{2}$ ratio shows a seasonal variation characterized by many short-term variations with time scales of several hours to several days (Fig. 2a); these fluctuations are not resolved by the flask measurements since the flask sampling was done every 4 days. Negative spikes of the $\mathrm{O}_{2} / \mathrm{N}_{2}$ ratio accompanied by positive $\mathrm{CO}_{2}$ spikes were observed especially between August and October (Fig. 2a). Monthly averaged standard deviations of anomaly $\mathrm{O}_{2} / \mathrm{N}_{2}$ ratio are 32.1, 18.3, and 16.0 for August, September, and October, respectively ( $n=29,28,30$, respectively), whereas monthly averaged standard deviations of anomaly APO are 13.2, 3.3, and 2.2, respectively ( $n=29,26,30$, respectively), where anomaly $\mathrm{O}_{2} / \mathrm{N}_{2}$ ratio and APO are daily averaged residuals that were de-trended and de-seasonalized from the observational data following Tohjima et al. (2008). The higher variability in the $\mathrm{O}_{2} / \mathrm{N}_{2}$ ratios, relative to the APO variability, should be attributed to terrestrial processes such as respiration of terrestrial biosphere and fossil fuel combustion. During the period from April to July, APO showed a large variability. Especially in late May to early July 2005, APO values were about 40 per meg higher than the APO values observed during the neighboring months, whereas, APO had no significant variabilities from October 2005 to March 2006 (Fig. 2b).

In fall and winter, mixed layer depth of the ocean increases because of the enhancement of ventilation and surface waters are mixed with subsurface waters, in which $\mathrm{O}_{2}$ is undersaturated. A decrease in the temperature of surface waters results in an increase in $\mathrm{O}_{2}$ solubility; the extent of undersaturation is enhanced. These factors should result in an uptake of atmospheric $\mathrm{O}_{2}$ into the oceans in fall and winter in the North Pacific near COI. At Trinidad Hed, California $\left(41.05^{\circ} \mathrm{N}, 124.15^{\circ} \mathrm{W}\right)$, strong coastal upwelling events occur from March to October, which transport the low-oxygen subsurface waters to the surface layer. The observed shortterm declines of APO lasting several days or weeks by tens to $\sim 100$ per meg, which should be attributed to the uptake of 

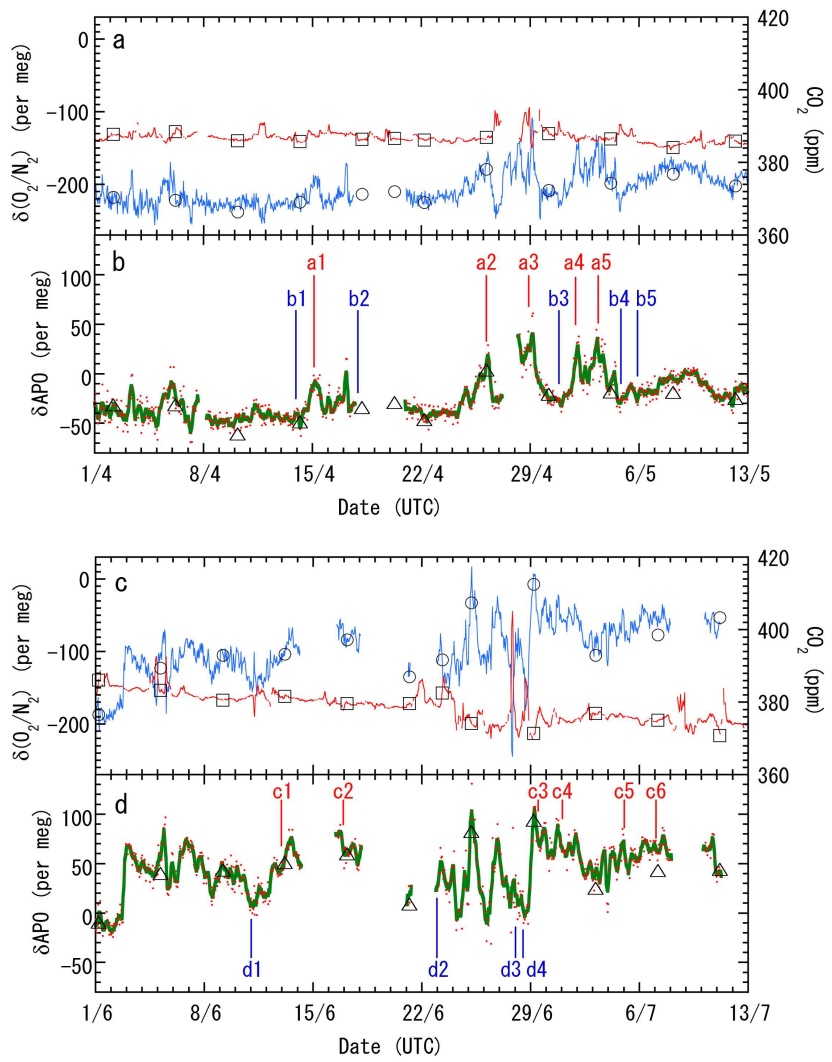

Fig. 5. One-hour mean $\mathrm{O}_{2} / \mathrm{N}_{2}$ ratio, $\mathrm{CO}_{2}$ mole fraction, and $\delta \mathrm{APO}$ at Cape Ochi-ishi for the periods of 1 April-12 May (a, b) and 1 July-12 July (c, d) in 2005. One-hour mean $\mathrm{O}_{2} / \mathrm{N}_{2}$ ratio (blue lines in a and $\mathrm{c}$ ), $\mathrm{CO}_{2}$ mole fraction (red lines in a and c), and $\delta \mathrm{APO}$ (red dots in $\mathrm{b}$ and $\mathrm{d}$ ), and 5-h running mean $\delta \mathrm{APO}$ (green lines in $\mathrm{b}$ and d) are shown. Dots represent the $\mathrm{O}_{2} / \mathrm{N}_{2}$ ratio (open circles in a and c), $\mathrm{CO}_{2}$ mole fraction (open squares in a and c), and $\delta \mathrm{APO}$ (open triangles in $\mathrm{b}$ and $\mathrm{d}$ ) of the flask samples. Times indicated by a1 to $\mathrm{d} 4$ in pointing $\delta \mathrm{APO}$ (in b and d) represent the starting times of the back trajectory calculations shown in Fig. 6a-d (see Sect. 3.3 for details). The numbers from 1 to 6 are comparable with those in the legends of Fig. 6.

atmospheric $\mathrm{O}_{2}$ into the low-oxygen sea waters (Lueker et al., 2003, 2004). However, such short-term negative spikes of APO were not observed in winter time (from December to February) at COI (Fig. 2b). Therefore, the $\mathrm{O}_{2}$ uptake in the western North Pacific near COI does not likely produce large heterogeneity of the atmospheric $\mathrm{O}_{2} / \mathrm{N}_{2}$ ratio in winter time.

\subsection{Oxygen emission related to spring bloom}

We focus on the APO variation from April to July 2005 (Fig. 5b and d) and examine the reasons for the high APO values during this period. We relate the APO variation at COI to the correlative patterns of the air mass transport (obtained through a back trajectory analysis) and the distribution of monthly-averaged marine net primary production (NPP), as shown in Fig. 6. We have computed the back trajecto- ries using the CGER/METEX Trajectory Model (Zeng et al., 2003) forced by a 3-d wind field on a sigma vertical coordinate; the altitude of the starting point is $500 \mathrm{~m}$, integrating back for $120 \mathrm{~h}$. Monthly NPP distribution is estimated from the Vertically Generalized Production Model (VGPM) (Behrenfeld and Falkowski, 1997), which is a widely used satellite-derived NPP estimation.

Because of the relatively rapid air-sea exchange of oxygen, re-equilibration of $\mathrm{O}_{2}$ in a mixed layer depth of $50 \mathrm{~m}$ occurs on a timescale of days (Gruber et al., 2001). Mixed layer depth is much less than $50 \mathrm{~m}$ (typically $5-30 \mathrm{~m}$ ) during spring bloom in the Japan Sea (Jo et al., 2007) and the Okhotsk Sea (Okunishi et al., 2005), and is about $50 \mathrm{~m}$ in the western North Pacific (Imai et al., 2002). Therefore, the time lag between $\mathrm{O}_{2}$ production and emission should be small (several days). In April 2005, the spring bloom occurred mainly in the Japan Sea and the region between $30^{\circ} \mathrm{N}$ and $40^{\circ} \mathrm{N}$ in the western North Pacific (Fig. 6a). High values of APO were observed at COI (red symbols from a1 to a5 in Fig. 5b) when the air mass trajectories passed over the high productive regions (Fig. 6a). On the other hand, low APO values were observed (blue symbols from b1 to b5 in Fig. 5b) when the air mass trajectories passed over the low productive regions (Fig. 6b). In June, high APO values (red symbols from c1 to c6 in Fig. 5d) were related to the strong bloom observed in the Okhotsk Sea and in the region $40 \sim 50^{\circ} \mathrm{N}$ in the western North Pacific (Fig. 6c), while low APO values (blue symbols from d1 to d4 in Fig. 5d) were related to air mass trajectories passing over the low productive regions (see Fig. 6d). Back trajectory analysis indicates that high values of APO are associated with air masses that have passed over the regions of active biological photosynthesis (spring bloom), showing that the $\mathrm{O}_{2}$ emission related to marine primary production can be observed by in-situ monitoring of atmospheric $\mathrm{O}_{2} / \mathrm{N}_{2}$ ratio and $\mathrm{CO}_{2}$ mole fraction.

We have made a rough estimation of the change in the oxygen flux from the marginal seas to evaluate the increase of APO by $\sim 100$ per meg between 28 June 12:00 (assigned as d4 in Fig. 5d) and 29 June 12:00 (assigned as c3 in Fig. 5d) by using a well-mixed moving column model that was used by Lueker et al. (2004) and Thompson et al. (2007). Sea-toair flux was estimated from the following equation (Jacob, 1999):

$F=\frac{\Delta C h}{t\{1-\exp (-L / u t)\}}$,

where $F$ is the sea-to-air flux of the species, $\Delta C$ is the change in its atmospheric mole fraction, $L$ is the wind fetch, $u$ is the wind speed, and $h$ is the vertical mixing height. We applied the following values to calculate the change in the oxygen flux: 100 permeg, $1530 \mathrm{~km}, 7.3 \mathrm{~ms}^{-1}, 290 \mathrm{~m}, 58 \mathrm{~h}$, for $\Delta C, L, u, h, t$, respectively. We estimated the wind fetch $(L)$ derived from the back trajectories. The starting point of the back trajectory calculation was set at $100 \mathrm{~m}$ above land surface (206 m above sea surface) and the wind fetch 


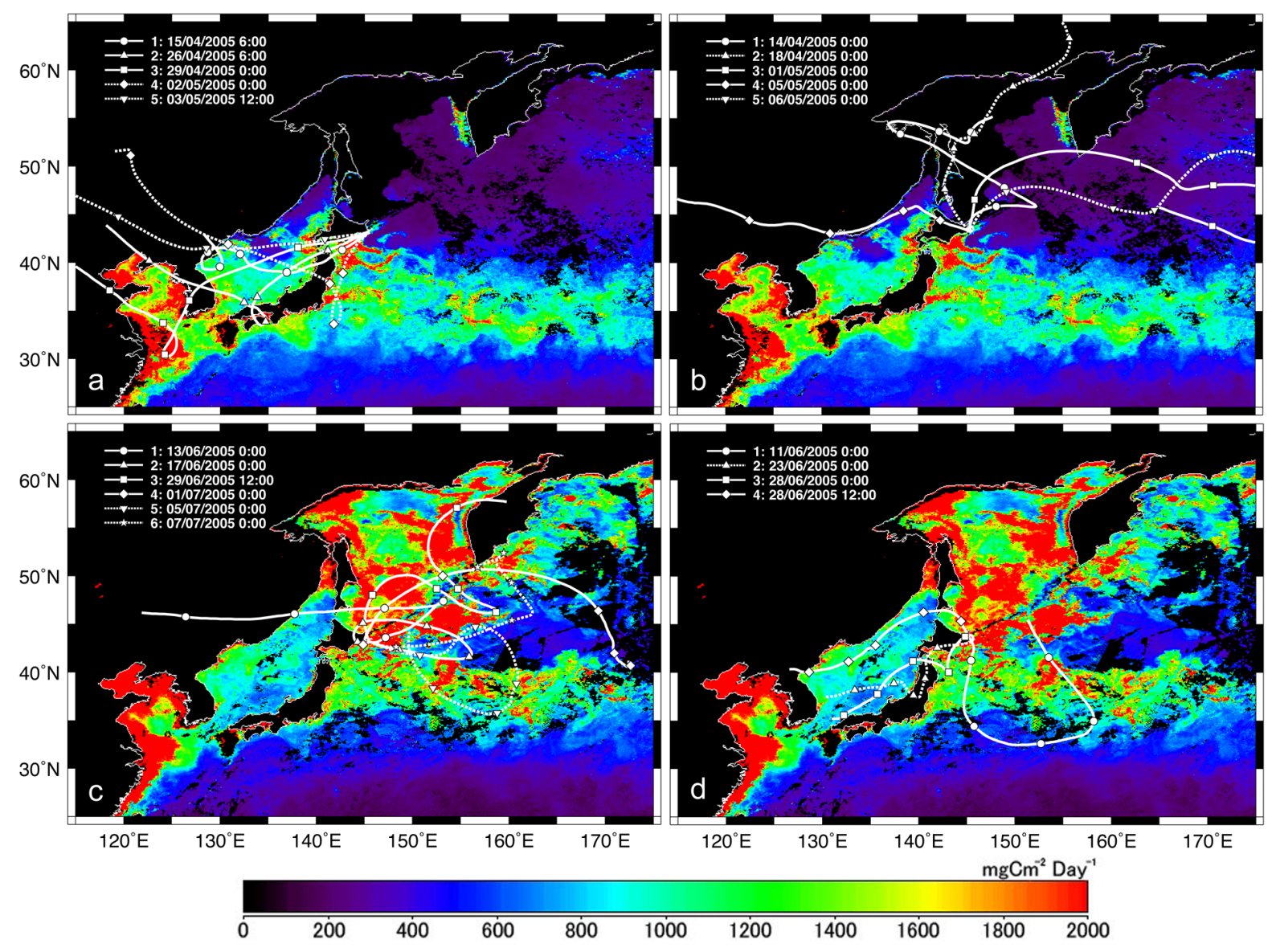

Fig. 6. Monthly-average distribution of the net primary production in April (a, b) and June (c, d) 2005 estimated from the Vertically Generalized Production Model (VGPM) (Behrenfeld and Falkowski, 1997), along with 5-day air mass back trajectories. The NPP estimation in the East China Sea and Yellow Sea might be overestimated due to suspended matter and chromophoric dissolved organic matter (He et al., 2000). Legends show the start time (UTC) for calculating back trajectories.

was summed until the air mass goes out of the boundary layer. Averaged wind speed $(u)$ and vertical mixing height (h) were also estimated based on the CGER/METEX Trajectory Model. We assumed that the variations of APO reflect changes of $\mathrm{O}_{2}$ mole fraction. With these assumptions, the increase of oxygen flux was estimated at $64 \mathrm{~mol} \mathrm{~m}^{-2} \mathrm{yr}^{-1}$. When we assume steady states and apply $\mathrm{O}_{2}: \mathrm{C}$ exchange ratio of 1.4 (Laws, 1991) for the net community productivity (NCP; the rate of gross production minus the rate of respiration by all metabolic processes), the difference of NCP can be estimated at $1.5 \times 10^{3} \mathrm{mgC} \mathrm{m}^{-2} \mathrm{day}^{-1}$. The NCP estimate based on oxygen flux may be comparable with the NPP estimate of the VGPM at the area of active production (Reuer et al., 2007). Our estimate of the NCP difference is consistent with the difference in NPP between the less active areas (beneath the trajectory No. 4 in Fig. 6d) and the active areas (beneath the trajectory No. 3 in Fig. 6c) within an order of magnitude.
Not all of the APO variability at COI, however, can be explained by the NPP-trajectory relationship. For example, a large increase in APO was observed on 3 June 2005 and an APO fluctuation on 24-27 June 2005. We are in the process of carrying out a detailed analysis of these events.

\section{Summary and implications}

We have been carrying out in-situ measurements of the atmospheric $\mathrm{O}_{2} / \mathrm{N}_{2}$ ratio at Cape Ochi-ishi (COI; $43^{\circ} 10^{\prime} \mathrm{N}$, $145^{\circ} 30^{\prime} \mathrm{E}$ ) in the northern part of Japan since March 2005 using the GC/TCD analyzer. The standard deviation of the $\mathrm{O}_{2} / \mathrm{N}_{2}$ ratio is estimated to be about \pm 14 per meg $(\approx 3 \mathrm{ppm})$ for the in-situ measurement system, resulting in a standard error of \pm 6 per meg $(\approx 1.2 \mathrm{ppm})$ for the 1 -h mean $\mathrm{O}_{2} / \mathrm{N}_{2}$ ratio. Although precision of the GC/TCD method is worse than that of the other in-situ measurement systems, the smaller consumption rate of working gas $\left(8 \mathrm{~mL} \mathrm{~min}^{-1}\right)$ is a benefit for long term observation at remote monitoring stations. 
After linearity correction in the in-situ measurement system, there remains a systematic bias for the $\mathrm{O}_{2} / \mathrm{N}_{2}$ ratio measured in situ compared with the $\mathrm{O}_{2} / \mathrm{N}_{2}$ ratio obtained from the flask measurements. The average of the differences between the in-situ and the flask measurements (5-h mean $\mathrm{O}_{2} / \mathrm{N}_{2}$ ratioflask data) is $7.0 \pm 9.9$ per meg $(1 \sigma, n=79)$ from March 2005 to March 2006.

During the period of our study, we have observed a clear seasonal variation in APO at COI. From late May to early July 2005, APO shows relatively high values, exceeding the values observed during the neighboring months by about 40 per meg, and is characterized by a large variability. Based on the results from trajectory analysis, it is suggested that the high values of APO at COI are associated with occurrences of strong marine primary production (spring bloom) observed in the Okhotsk Sea and the western North Pacific. This gives additional support to the idea that the variation in APO reflects variation in $\mathrm{O}_{2}$ emission associated with the spring bloom of phytoplankton in the western North Pacific and marginal seas near Japan.

Acknowledgements. We are thankful to F. Shimano, H. Sakai, K. Sengoku, and N. Oda for maintenance of our in-situ measurement system. We thank $\mathrm{S}$. Hashimoto for processing $\mathrm{CO}_{2}$ data and A. Watanabe for writing software programs for measurement. We thank J. Zeng for providing back trajectory analysis tools and supporting us to use them. We also thank S. Maksyutov, Y. Koyama, R. F. Keeling, N. Cassar, Y. Yamanaka, H. Tanimoto, T. Machida, K. Shimoyama, and T. Saino for valuable discussions. Monitoring station is maintained by the Center for Global Environmental Research (CGER) and Global Environmental Forum (GEF). This work was supported by the Global Environment Research Coordination System of the Ministry of the Environment, Japan and partly supported by the Grants-in-Aid for Creative Scientific Research (2005/17GS0203) of the Ministry of Education, Science, Sports and Culture, Japan.

Edited by: T. Röckmann

\section{References}

Balkanski, Y., Monfray, P., Battle, M., and Heimann, M.: Ocean primary production derived from satellite data: An evaluation with atmospheric oxygen measurements, Global Biogeochem. Cy., 13(2), 257-271, 1999.

Battle, M., Bender, M., Hendricks, M. B., Ho, D. T., Mika, R., McKinley, G., Fan, S. M., Blaine, T., and Keeling, R. F.: Measurements and models of the atmospheric $\mathrm{Ar} / \mathrm{N}_{2}$ ratio, Geophys. Res. Lett., 30(15), 1786, doi:10.1029/2003GL017411, 2003.

Battle, M., Fletcher, S. M., Bender, M. L., Keeling, R. F., Manning, A. C., Gruber, N., Tans, P. P., Hendricks, M. B., Ho, D. T., Simonds, C., Mika, R., and Paplawsky, B.: Atmospheric potential oxygen: New observations and their implications for some atmospheric and oceanic models, Global Biogeochem. Cy., 20(1), GB1010, doi:10.1029/2005GB002534, 2006.
Behrenfeld, M. J. and Falkowski, P. G.: Photosynthetic rates derived from satellite-based chlorophyll concentration, Limnol. Oceanogr., 42(1), 1-20, 1997.

Bender, M., Ellis, T., Tans, P., Francey, R., and Lowe, D.: Variability in the $\mathrm{O}_{2} / \mathrm{N}_{2}$ ratio of southern hemisphere air, 19911994: Implications for the carbon cycle, Global Biogeochem. Cy., 10(1), 9-21, 1996.

Bender, M. L., Tans, P. P., Ellis, J. T., Orchardo, J., and Habfast, K.: A high-precision isotope ratio mass-spectrometry method for measuring the $\mathrm{O}_{2} / \mathrm{N}_{2}$ ratio of air, Geochim. Cosmochim. Ac., 58(21), 4751-4758, 1994.

Blaine, T. W., Keeling, R. F., and Paplawsky, W. J.: An improved inlet for precisely measuring the atmospheric $\mathrm{Ar} / \mathrm{N}_{2}$ ratio, Atmos. Chem. Phys., 6, 1181-1184, 2006, http://www.atmos-chem-phys.net/6/1181/2006/.

Broecker, W. S. and Peng, T.-H.: Tracers in the Sea, Eldigio Press, New York, 1982.

Gruber, N., Gloor, M., Fan, S. M., and Sarmiento, J. L.: Air-sea flux of oxygen estimated from bulk data: Implications for the marine and atmospheric oxygen cycles, Global Biogeochem. Cy., 15(4), 783-803, 2001.

He, M. X., Liu, Z. S., Du, K. P., Li, L. P., Chen, R., Carder, K. L., and Lee, Z. P.: Retrieval of chlorophyll from remote-sensing reflectance in the China seas, Appl. Optics, 39(15), 2467-2474, 2000.

Imai, K., Nojiri, Y., Tsurushima, N., and Saino, T.: Time series of seasonal variation of primary productivity at station KNOT (44 degrees N, 155 degrees E) in the sub-arctic western North Pacific, Deep-Sea Res. II, 49(24-25), 5395-5408, 2002.

Jacob, D.: Introduction to Atmospheric Chemistry, Princeton Univ. Press, Princeton, N. J., USA, 266 pp., 1999.

Jo, C. O., Lee, J. Y., Park, K. A., Kim, Y. H., and Kim, K. R.: Asian dust initiated early spring bloom in the northern East/Japan Sea, Geophys. Res. Lett. 34(5), L05602, doi:10.1029/2006GL027395, 2007.

Keeling, R. F.: Development of an interferometric oxygen analyzer for precise measurements of the atmospheric $\mathrm{O}_{2}$ mole fraction., $\mathrm{PhD}$ thesis, Harvard University, USA, 1988.

Keeling, R. F. and Shertz, S. R.: Seasonal and Interannual Variations in Atmospheric Oxygen and Implications for the Global Carbon-Cycle, Nature, 358(6389), 723-727, 1992.

Keeling, R. F., Manning, A. C., McEvoy, E. M., and Shertz, S. R.: Methods for measuring changes in atmospheric $\mathrm{O}_{2}$ concentration and their application in southern hemisphere air, J. Geophys. Res.-Atmos., 103(D3), 3381-3397, 1998.

Keeling, R. F., Blaine, T., Paplawsky, B., Katz, L., Atwood, C., and Brockwell, T.: Measurement of changes in atmospheric $\mathrm{Ar} / \mathrm{N}_{2}$ ratio using a rapid-switching, single-capillary mass spectrometer system, Tellus B, 56(4), 322-338, doi: 10.1111/j.16000889.2004.00117.x, 2004.

Laws, E. A.: Photosynthetic Quotients, New Production and Net Community Production in the Open Ocean, Deep-Sea Res., 38(1), 143-167, 1991.

Lueker, T. J., Walker, S. J., Vollmer, M. K., Keeling, R. F., Nevison, C. D., Weiss, R. F., and Garcia, H. E.: Coastal upwelling air-sea fluxes revealed in atmospheric observations of $\mathrm{O}_{2} / \mathrm{N}_{2}, \mathrm{CO}_{2}$ and $\mathrm{N}_{2} \mathrm{O}$, Geophys. Res. Lett., 30(60), 1292, doi: 10.1029/2002GL016615, 2003.

Lueker, T. J.: Coastal upwelling fluxes of $\mathrm{O}_{2}, \mathrm{~N}_{2} \mathrm{O}$, and $\mathrm{CO}_{2}$ as- 
sessed from continuous atmospheric observations at Trinidad, California, USA, Biogeosciences, 1, 101-111, 2004, http://www.biogeosciences.net/1/101/2004/.

Manning, A. C., Keeling, R. F., and Severinghaus, J. P.: Precise atmospheric oxygen measurements with a paramagnetic oxygen analyzer, Global Biogeochem. Cy., 13(4), 1107-1115, 1999.

Manning, A. C.: Temporal variability of atmospheric oxygen from both continuous measurements and flask sampling network: Tools for studying the global carbon cycle, $\mathrm{PhD}$ thesis, University of Callifornia, San Diego, USA 2001.

Manning, A. C. and Keeling, R. F.: Global oceanic and land biotic carbon sinks from the Scripps atmospheric oxygen flask sampling network, Tellus B, 58(2), 95-116, 2006.

Mukai, H., Katsumoto, M., Ide, R., Machida, T., Fujinuma, Y., Nojiri, Y., Inagaki, M., Oda, N., and Watai, T.: Characterization of atmospheric $\mathrm{CO}_{2}$ observed at two-background air monitoring stations (Hateruma and Ochi-ishi) in Japan, in: Sixth International Carbon Dioxide Conference, Extended Abstract, Vol. I, edited by: Tohoku University, Japan, Sendai, Japan, 108-111, 2001.

Okunishi, T., Kishi, M. J., Shiomoto, A., Tanaka, H., and Yamashita, T.: An ecosystem modeling study of spatio-temporal variations of phytoplankton distribution in the Okhotsk Sea, Cont. Shelf Res., 25(12-13), 1605-1628, 2005.

Reuer, M. K., Barnett, B. A., Bender, M. L., Falkowski, P. G., and Hendricks, M. B.: New estimates of Southern Ocean biological production rates from $\mathrm{O}_{2} / \mathrm{Ar}$ ratios and the triple isotope composition of $\mathrm{O}_{2}$, Deep-Sea Res. I, Oceanogr. Res. Pap., 54(6), 951974, doi:10.1016/j.dsr.2007.02.007, 2007.

Severinghaus, J. P.: Studies of the terrestrial $\mathrm{O}_{2}$ and carbon cycles in sand dune gases and in Biosphere 2., PhD thesis, Columbia Univ., USA, 1995.

Stephens, B. B., Keeling, R. F., Heimann, M., Six, K. D., Murnane, R., and Caldeira, K.: Testing global ocean carbon cycle models using measurements of atmospheric $\mathrm{O}_{2}$ and $\mathrm{CO}_{2}$ concentration, Global Biogeochem. Cy., 12(2), 213-230, 1998.

Stephens, B. B.: Field-based Atmospheric Oxygen Measurements and the Ocean Cycle, $\mathrm{PhD}$ thesis, Scripps Institution of Oceanography, Univ. of Calif., San Diego, USA, 1999.

Stephens, B. B., Keeling, R. F., and Paplawsky, W. J.: Shipboard measurements of atmospheric oxygen using a vacuum-ultraviolet absorption technique, Tellus B, 55(4), 857-878, 2003.
Stephens, B. B., Bakwin, P. S., Tans, P. P., Teclaw, R. M., and Baumann, D. D.: Application of a differential fuel-cell analyzer for measuring atmospheric oxygen variations, J. Atmos. Ocean. Tech., 24(1), 82-94, 2007.

Sturm, P., Leuenberger, M., Valentino, F. L., Lehmann, B., and Ihly, B.: Measurements of $\mathrm{CO}_{2}$, its stable isotopes, $\mathrm{O}_{2} / \mathrm{N}_{2}$, and ${ }^{222} \mathrm{Rn}$ at Bern, Switzerland, Atmos. Chem. Phys., 6, 1991-2004, 2006, http://www.atmos-chem-phys.net/6/1991/2006/.

Thompson, R. L., Manning, A. C., Lowe, D. C., and Weatherburn, D. C.: A ship-based methodology for high precision atmospheric oxygen measurements and its application in the Southern Ocean region, Tellus B, 59(4), 643-653, doi:10.1111/J.16000889.2007.00292.X, 2007.

Tohjima, Y.: Method for measuring changes in the atmospheric $\mathrm{O}_{2} / \mathrm{N}_{2}$ ratio by a gas chromatograph equipped with a thermal conductivity detector, J. Geophys. Res.-Atmos., 105(D11), 14 575-14 584, 2000.

Tohjima, Y., Mukai, H., Machida, T., and Nojiri, Y.: Gas-chromatographic measurements of the atmospheric oxygen/nitrogen ratio at Hateruma Island and Cape Ochi-ishi, Japan, Geophys. Res. Lett., 30(12), 1653, doi:10.1029/2003GL017282, 2003.

Tohjima, Y., Mukai, H., Nojiri, Y., Yamagishi, H., and Machida, T.: Atmospheric $\mathrm{O}_{2} / \mathrm{N}_{2}$ measurements at two Japanese sites: estimation of global oceanic and land biotic carbon sinks and analysis of the variations in atmospheric potential oxygen (APO), Tellus B, 60(2), 213-225, doi:10.1111/J.1600-0889.2007.00334.X, 2008.

Tohjima, Y., Machida, T., Watai, T., Akama, I., Amari, T., and Moriwaki, Y.: Preparation of gravimetric standards for measurements of atmospheric oxygen and reevaluation of atmospheric oxygen concentration, J. Geophys. Res.-Atmos., 110, D11302, doi:10.1029/2004JD005595, 2005a.

Tohjima, Y., Mukai, H., Machida, T., Nojiri, Y., and Gloor, M.: First measurements of the latitudinal atmospheric $\mathrm{O}_{2}$ and $\mathrm{CO}_{2}$ distributions across the western Pacific, Geophys. Res. Lett., 32, L17805, doi:10.1029/2005GL023311, 2005b.

Zeng, J., Katsumoto, M., Ide, R., Inagaki, M., Mukai, H., and Fujinuma, Y.: Development of meteorological data explorer for Windows, in: Data Analysis and Graphic Display System for Atmospheric Research using PC, CGER-M014-2003, edited by: Fujinuma, Y., Center for Global Environmental Research/NIES, Tsukuba, Japan, 19-73, 2003. 